\title{
Country and regional carbon stock in forest cover - estimates based on the first cycle of the Czech National Forest Inventory data (2001-2004)
}

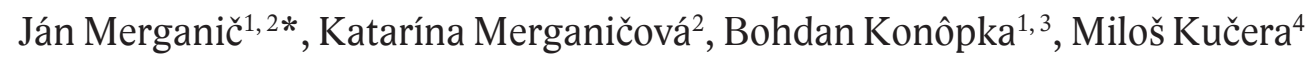

${ }^{1}$ Czech University of Life Sciences, Faculty of Forestry and Wood Sciences, Kamýcká 1176, CZ - 16521 Prague 6 - Suchdol, Czech Republic

${ }^{2}$ Technical University in Zvolen, Faculty of Forestry, T. G. Masaryka 24, SK-960 53 Zvolen, Slovak Republic

${ }^{3}$ National Forest Centre, Forest Research Institute Zvolen, T. G. Masaryka 2175/22, SK - 96092 Zvolen, Slovak Republic

${ }^{4}$ Forest Management Institute (ÚHÚL), Nábřežní 1326, CZ - 25001 Brandýs nad Labem - Stará Boleslav, Czech Republic

\begin{abstract}
Since forests can play an efficient role in the mitigation of greenhouse gas emissions, objective information about the actual carbon stock is very important. Therefore, the presented paper analysed the carbon stock in the living merchantable trees (with diameter at breast height above $7 \mathrm{~cm}$ ) of the Czech forests with regard to groups of tree species and tree compartments (wood under bark with diameter above $7 \mathrm{~cm}$, wood under bark with diameter below $7 \mathrm{~cm}$, bark, green twigs, foliage, stump and roots). We examined its regional distribution and relationship to the number of inhabitants and the gross domestic product. The data used for the analysis originated from 13,929 forest plots of the first Czech National Forest Inventory performed between 2001 and 2004. The total tree carbon stock was obtained as a sum of the carbon stock in the individual tree compartments estimated from the biomass amount in the compartments multiplied by the relative carbon content. Wood biomass amount was calculated by multiplying a particular part of tree volume with species-specific green wood density. The total amount of carbon stored in forest trees in the Czech Republic was over 327 mill. $t$, which is about $113 \mathrm{t}$ of carbon per ha of forests. The highest carbon amount (160 mill. t, i.e. $49.0 \%$ of the total amount) was fixed in spruce. The minimum carbon amount fixed in the forest cover (14.35 mill. t) was calculated for Ústecký kraj (region), while the maximum carbon amount (51.51 mill. t) was found in Jihočeský kraj.
\end{abstract}

Key words: carbon; forest biomass; tree compartments; tree species composition; allometric equation

\section{Introduction}

Although the Czech Republic belongs to countries with an average forest cover in Europe, its wood stock per hectare exceeds the European average (Forest Europe 2015). At the same time, the forest area as well as the hectare wood stock of the country and the total standing wood stock have been increasing over the last decades. For instance, while in the year 1950 the total estimated wood stock (expressed as wood with diameter $>7 \mathrm{~cm}$ without bark) from the Summarised Forest Management Plans was 322 mill. $\mathrm{m}^{3}$, in 1980 it increased to 536 mill. $\mathrm{m}^{3}$ and in 2010 to as much as 681 mill. $\mathrm{m}^{3}$ (MACR 2016). However, the total growing stock derived from the first National Forest Inventory (NFI) data (2001-2004) was significantly higher (900 mill. m³ Štěrba \& Jankovská 2007; Kučera et al. 2014) in comparison to 658 mill. $\mathrm{m}^{3}$, which was the estimated growing stock in 2004 derived from the Forest Management Plans used in official statistics. The growing stock derived from the second NFI (2011-2014) is 935.8 mill. $\mathrm{m}^{3}$ and is higher than in the first NFI and confirms the trend of the increasing growing stock in the Czech Republic. These estimates indicate that thanks to the gradually increasing forest biomass the country takes an active part in the whole European trend to increase forest stocks and carbon reserves sequestrated in it (Lindner \& Karjalainen 2007).

Intensive utilisation of land by humans modifies carbon sequestration and emissions in/from forests or other ecosystems as well as the soil. Thus, it is necessary to monitor, and analyse these impacts at specific levels (regional, national, continental and global), and to control them on the base of the actual situation. The United Nations initiated the Framework Convention about Cli- 
mate Change covering also Land Use, Land-Use Change and Forestry (LULUCF, IPCC 2003). The LULUCF activities related to the expansion of forest area and the increase of forest stocks focus on carbon absorption from the atmosphere (see e.g. MacDicken 2015). To optimise human impacts on forests for carbon sequestration, we should have the knowledge about the landscape state, specifically the structure of different types of ecosystems (forests, grasslands, agricultural lands, wetlands, etc.) including their spatial arrangement.

From the point of land utilisation and management, three main strategies to increase the amount of carbon in ecosystems are considered: 1) maintaining carbon sequestration in forests, 2) changes on agricultural lands aimed at reduction of arable fields (prevailingly in the form of afforestation), 3) conservation of the currently existing carbon storage pools, especially vegetation on wetlands and in old-growth forests (Janssens et al. 2005). Forests, and especially afforestation measures and measures leading to the increase of hectare wood stock, are considered to be the most efficient carbon sequestration systems (see also MacDicken 2015). In general, large differences in forest cover as well as in hectare stock exist not only between individual countries but also at intracountry level, i.e. between individual regions within one country (Andronache et al. 2017). The variability in forest cover among countries and administrative regions results from different political settings, socioeconomic conditions, ownership structure and management practices in the past and present (Cvitanovic et al. 2016, Andronache et al. 2017). At a global level, Keenan et al. (2015) revealed that forest cover increases with the increasing income of the region or the country, while Crespo Cuaresma et al. (2017) revealed a U-shaped relationship between the income per capita and the forest cover of countries. The information about the conditions in specific regions, e.g. administrative units, is necessary for strategic decision-making at a national level. A "dissection" on current situation in forest biomass quantity (amount of fixed carbon) is important particularly for the Czech Republic seeing that the government has declared to support afforestation as an essential part of its national rural developmental program (Forest Europe 2015).

For the estimation of biomass in forest cover, i.e. also carbon accumulated in trees, a variety of terrestrial and aerial methods can be applied. Most developed countries conduct regular national inventories of their forests, which provide valuable data for the estimation of carbon stock at least at a national level, and possibly also at certain regional scales, if they are based on statistically sound design and permanent inventory plots (e.g. Brown 2002). In such cases, individual tree characteristics measured at inventory plots are used in functions for tree biomass estimation. Three methods are frequently used to calculate biomass at a tree level (Brown 1997; West 2010): (1) allometric equations, in which tree height or/ and stem diameter are most commonly used independent variables, (2) expansion factors used for multiplying stem volume as an independent variable, and (3) combination of the first two methods.

As the first NFI in the Czech Republic was performed just at the beginning of the $21^{\text {st }}$ century, the data for the estimation of the actual biomass in forest cover have become available. In 2014 and 2016, the Forest Management Institute estimated the amount of aboveground biomass of trees with tree height $\geq 10 \mathrm{~cm}$ from NFI 1 and NFI2 data using the allometric equations of four main tree species - spruce, pine, oak and beech (Kučera et al. 2014, 2016). The presented paper uses the combined approach of biomass estimation, since the biomass of wood and bark was derived from wood volume, and the allometric equations were used only for the calculation of foliage and root biomass.

The main ambition of this paper was to quantify and analyse carbon stock in merchantable forest biomass (i.e. in living trees with diameter at breast height $\geq 7 \mathrm{~cm}$ ) on the base of the first NFI data using a combined method of calculating carbon stock. We focused on the merchantable part of forest ecosystems because it sequesters most of the carbon and is most significantly influenced by human activities. The specific goals of the work were as follows:

1. To present and describe a combined method of biomass estimation based on the calculation of tree and bark volume using species-specific volume equations and models of stem shape, and the calculation of foliage and root biomass using species-specific allometric equations.

2. To quantify carbon stock of the Czech Republic using this method at a national level with regard to individual tree species and individual tree compartments (i.e. foliage, branches, stem under bark, stem bark, and roots) because both tree species and/or compartments differ in their life expectancy and hence, in their carbon sequestration capacity (Loehle 1987; Steele et al. 1997; Helmisaari et al. 2002). In addition, they are also influenced by different management and harvesting practices that reflect the species composition of the stands. Due to this, their current share in the carbon stock may indicate future development of carbon stock.

3. To analyse the regional distribution of carbon stock considering the current administrative units and to examine the relationship of the carbon stock to the number of inhabitants and the regional gross domestic product (GDP) because forest cover is known to be dependent on population density (Li et al. 2013; Van Noordwijk \& Villamor 2014; Thorn et al. 2016) and income (Keenan et al. 2015; Crespo Cuaresma et al. 2017).

We believe that the outcome of such analyses may create the information basis for decision-making at both regional and national levels, because it is an inductive method based on "bottom-up" principles. 


\section{Material and Methods}

\subsection{Empirical data}

The data used for the analysis originate from the NFI1 in the Czech Republic. The NFI in the Czech Republic is set by Act No. 289/1995 coll., on Forests and Amendments to some Acts (The Forestry Act) and the Governmental Regulation No. 193/2000 coll. They declared the implementation of the forest inventory for the period from 2001 to 2004. The NFI in the Czech Republic has been conducted by the Forest Management Institute (FMI) in Brandys nad Labem which is also responsible for NFI data management and data processing.

The applied sampling design of NFI was based on the systematic group sampling in a grid size of $2 \times 2 \mathrm{~km}$ (Fig. 1). Two permanent circular plots were established in each grid cell. The position of the first inventory plot was randomly generated within a circle with a radius of $300 \mathrm{~m}$ around the centre of the inventory grid cell. The plot was established if the plot centre was located within the category of forest. The distance between the inventory plots of the same cell was set to constant $300 \mathrm{~m}$, while the direction from the first to the second plot was random (Štěrba \& Jankovská 2007). Between the years 2001 and 2004, 39,460 plots were established in total, out of which 25,531 were non-forest plots, and 13,929 were forest plots located in 8,705 grid cells of $2 \times 2 \mathrm{~km}$.

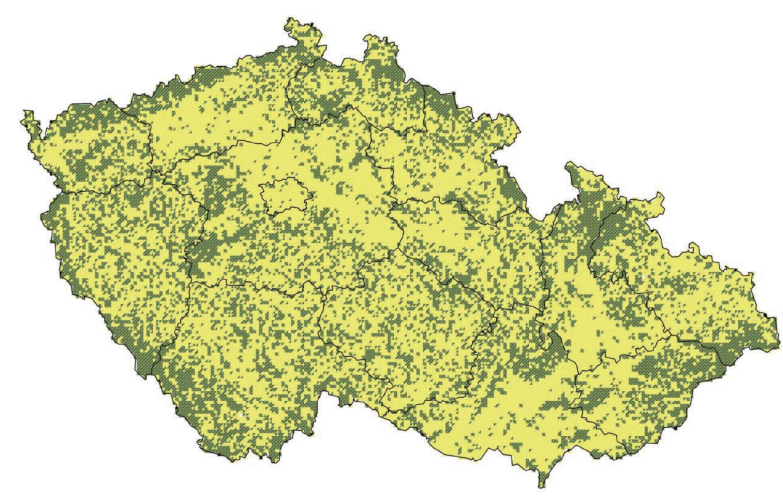

Fig. 1. The map indicates the positions of the NFI plots (first cycle performed during the years of 2001-2004) on the territory of the Czech Republic and their categorisation as forest or non-forest.

Legend: - forest, _ _ non-forest, - border of the region.

Each plot was stratified into segments with regard to the specific classes of the land cover. The segment should have a minimum size of $10 \%$ of the area of the inventory plot. The plot was a fixed circle of $500 \mathrm{~m}^{2}$ for the trees with diameter at breast height $(D B H)$ greater or equal to $12 \mathrm{~cm}$. For the trees with $D B H$ between 7 and $11.9 \mathrm{~cm}$ and for the regeneration with height $\geq 10 \mathrm{~cm}$ additional two concentric circles were established in the centre of gravity (location of maximum distance to seg- ment boundaries) of each polygonal segment of the plot. For the first group a circle with a radius of $3 \mathrm{~m}$ and for the second group a circle with a radius of $2 \mathrm{~m}$ was established. The number of investigated primary (field) variables per plot was approximately 150 (Štěrba \& Jankovská 2007).

For this work we used tree data of standing living trees with $D B H$ over $6.9 \mathrm{~cm}$ over bark was measured on every tree over the registration threshold $(7 \mathrm{~cm})$ with precision in mm over bark. Tree height was measured on a sample of trees with the following criteria: maximum 50 trees per species on one plot, standing living trees without fresh stem breakage, stem bending or forking below the height of $7 \mathrm{~m}$. If no height was measured for a particular species on a subplot, a model height was used. The model was developed using the data from other inventory plots.

\subsection{Biomass and carbon estimate}

Mean tree volume was calculated using two-parameter regressions derived for volume tables of Czechoslovakia by Petráš \& Pajtík (1991). The authors compiled over 30-year long work in this field in former Czechoslovakia, enhanced some equations and presented the calculation of the following volumes:

- Stem volume under bark $(S V U B)$

- Stem volume over bark $(S V O B)$

- Tree volume over bark (TVOB)

- Volume of wood with diameter above $7 \mathrm{~cm}$ under bark (VWUB)

- Volume of wood with diameter above $7 \mathrm{~cm}$ over bark (VWOB).

From these volumes we also derived tree volume under bark (TVUB) using the procedure described at the end of this section. All volumes are calculated for the particular parts of the tree excluding the stump part (Petráš 1984).

The two parameters in all the functions are tree diameter at breast height $(D B H)$ and tree height $(h)$. Hence, the general form of the relationship is

$$
v=f(D B H, h)
$$

The formula and the coefficients used in the equations are presented in Petráš \& Pajtík (1991) in the form of a computer program for 11 tree species: 7 broadleaved (beech, oak, hornbeam, birch, ash, poplar, poplar clone, alder) and 4 coniferous tree species (spruce, fir, pine, larch). The equations were derived from felled sample trees measured in $2 \mathrm{~m}$ sections including stem and crown woody parts. The collection of empirical data accounted for the regional variability of species composition in the former Czechoslovakia. Hence, the proportion of sample trees from the Czech Republic varied between individual tree species as shown in Table 1 also shows the original authors of the equations. 
Table 1. Number of sample trees by tree species used for the creation of volume equations and volume tables derived for the former Czechoslovakia and the authors of the volume equations (information taken from Petráš \& Pajtík 1991; Šmelko 2000).

\begin{tabular}{lccl}
\hline \multicolumn{1}{c}{ Tree species } & Number of sample trees & \% from the Czech Republic & \multicolumn{1}{c}{$\begin{array}{c}\text { Original authors } \\
\text { *Authors of amendments }\end{array}$} \\
\hline Norway spruce & 2,111 & 71 & Korsuň (1961) - *Hubač \& Pánek (1979) \\
Silver fir & 1,477 & 27 & Hubač \& Šebík (1963) - *Hubač \& Pánek (1979) \\
Scots pine & 1,659 & 76 & Korsuň (1962) - *Hubač \& Pánek (1979) \\
Deciduous larch & 1,293 & 74 & Čermák et al. (1984) \\
Oaks & 1,893 & 40 & Čermák (1976) \\
European beech & 1,886 & 21 & Hubač (1977) \\
Common hornbeam & 1,535 & 55 & Čermák (1980) \\
Birches & 1,355 & 60 & Košút et al. (1985) \\
Common ash & 1,166 & 40 & Hubač et al. (1987) \\
Poplars & 1,480 & 64 & Korsuň (1967) - *Halaj \& Petráš (1981) \\
Alders & 2,232 & 94 & Korsuň (1966) - *Rehák (1981), Petráš \& Pajtík (1991) \\
\hline Sum & 20,357 & 58 & All above-listed authors \\
\hline
\end{tabular}

For other species, for which no volume equations were available, the formulas and the coefficients of the most similar tree species (based on genus and family similarities) were used.

In addition, we also calculated stem volume under bark using the integral equation (ISVUB), which was based on the models of stem shape derived by Petráš $(1986,1989,1990)$. The general formula is

$$
v=\frac{\pi}{40000} \times \int_{0}^{h} d\left(h_{i}, h, D B H, \vec{a}, s p\right)^{2} d h
$$

where:

$$
\begin{array}{ll}
v=\text { ISVUB } & - \text { stem volume under bark in } \mathrm{m}^{3}, \\
h & - \text { tree height in } \mathrm{m}, \\
D B H & - \text { tree diameter at } 1.3 \mathrm{~m} \text { height in } \mathrm{cm}, \\
d & - \text { tree diameter at the } \mathrm{i}^{\text {th }} \text { tree height }\left(h_{\mathrm{i}}\right) \text { in } \mathrm{cm}, \\
a & \text { - vector of tree-species specific parameters in the } \\
& \text { model of stem shape, } \\
s p & \text { - tree species. }
\end{array}
$$

The integral equation presented above was used only for the calculation of the integral stump volume (IVS). The stump height was equal to a modelled height calculated using the equation of Petráš $(1986,1989,1990)$ :

$$
h_{\text {stump }}=a+b \times h^{c}
$$

where:

$$
\begin{array}{ll}
a, b, c & \text { - regression coefficients, } \\
h & - \text { tree height in } \mathrm{m} .
\end{array}
$$

By dividing the integral stump volume IVS with $I S V U B$ we obtained the relative proportion of the stump volume from the stem volume under bark (\%VS).

$$
\% V S=I V S / I S V U B \times 100
$$

The stump volume (VS) was calculated by multiplying \%VS with $S V U B$ derived according to Petráš \& Pajtík (1991).

$$
V S=\% V S \times S V U B / 100
$$

From the calculated volumes we also derived wood volume with diameter below $7 \mathrm{~cm}$, volume and the proportion of bark as follows:

Wood volume with diameter below $7 \mathrm{~cm}$ over bark $($ VWOBT)

$$
V W O B T=T V O B-V W O B
$$

Proportion of bark for wood with diameter below $7 \mathrm{~cm}$

$(\%$ bark $)=\max \left(\left(\frac{V W O B-V W U B}{V W O B}\right) ;\left(\frac{S V O B-S V U B}{S V O B}\right)\right)$

Proportion of bark on stump $=$

$$
\min \left(\left(\frac{V W O B-V W U B}{V W O B}\right) ;\left(\frac{S V O B-S V U B}{S V O B}\right)\right)
$$

Wood volume with diameter below $7 \mathrm{~cm}$ under bark $(V W U B T)$ :

$$
V W U B T=V W O B T \times(1-\% \text { bark })
$$

Volume of bark:

$$
(\text { Vbark })=T V O B-(V W U B+V W U B T)
$$

The maximum and minimum functions in equations [7] and [8], respectively, were applied to consider the negative relationship between the proportion of bark and diameter of wood (Šmelko 2000).

Tree volume under bark (TVUB) was calculated as a sum of wood volume with diameter above and below 7 cm under bark:

$$
T V U B=V W U B+V W U B T
$$

The methodology of biomass estimation was based on the regional studies from the former Czechoslovakia (Petráš et al. 1985; Chmelař 1992; Požgaj et al. 1993; Cienciala et al. 2008). Where regional studies were not available, we used studies published elsewhere (Drexhage \& Colin 2001; Miles \& Smith 2009) or we approximated the values with similar species. As we only had data about trees with diameter at breast height equal to or above $7 \mathrm{~cm}$, we calculated biomass only for this group of trees. The total biomass of a mean tree consisted of the biomass of merchantable wood under bark with diameter equal to or above $7 \mathrm{~cm}\left(B_{W U B}\right)$, biomass of wood under bark with diameter below $7 \mathrm{~cm}\left(B_{W U B T}\right)$, biomass of bark $\left(B_{\text {Bark }}\right)$, biomass of green twigs $\left(B_{\text {gtwigs }}\right)$, biomass of foliage $\left(B_{\text {foliage }}\right)$, and biomass of stump and roots $\left(B_{\text {stump }+ \text { roots }}\right)$. $B=B_{W U B}+B_{W U B T}+B_{\text {Bark }}+B_{\text {gtwigs }}+B_{\text {foliage }}+B_{\text {stump }+ \text { roots }}$

The biomass of wood under bark was defined as ovendry biomass of wood under bark with diameter equal to 
or above $7 \mathrm{~cm}$. It is calculated by multiplying the volume of wood under bark with diameter equal to or above 7 $\mathrm{cm}(V W U B)$ with green wood density $\left(D_{g w}\right)$ of particular species given in Table 2 taken from Klement et al. (2010), Miles \& Smith (2009), Meier (2013), Tümen \& Hafizoglu (2002).

$$
B_{V W U B}=V W U B \times D_{g w}
$$

Green wood density was defined as the ratio between the oven-dry wood mass (kg) and green (fresh) wood volume $\left(\mathrm{m}^{3}\right)$.

The biomass of wood under bark with diameter below $7 \mathrm{~cm}$ was calculated by multiplying the volume of wood under bark with diameter below $7 \mathrm{~cm}$ with green wood density of particular species and correction index $I_{W U B T^{*}}$ The values of the correction index were derived from the values published by Požgaj et al. (1993) and Chmelař (1992).

$$
B_{W U B T}=V W U B T \times D_{g w} \times I_{W U B T}
$$

The biomass in bark was calculated by multiplying the volume of bark with green wood density of particular species and correction index $I_{b a r k}$ representing the ratio between bark and wood density. The values of the correction index for individual tree species were derived from the study of Miles \& Smith (2009).

$$
B_{\text {Bark }}=\operatorname{Vbark} \times D_{g w} \times I_{b a r}
$$

The biomass in green twigs $\left(B_{\text {gtwigs }}\right)$, biomass in foliage $\left(B_{\text {foliage }}\right)$, and biomass in stump and roots $\left(B_{\text {stump }+ \text { roots }}\right)$ were calculated using the two-parameter functions with tree diameter at breast height $(D B H$ in $\mathrm{cm})$ and tree height ( $h$ in $\mathrm{m}$ ) as independent variables entering the models published by different authors. The biomass in green twigs $\left(B_{\text {gtwigs }}\right)$ and biomass in foliage $\left(B_{\text {foliage }}\right)$ were calculated following the method published by Petráš et al. (1985). The authors published equations for three species: spruce, pine and beech. The biomass in stump and roots was calculated using the work of Drexhage \& Colin (2001). The authors derived the coefficients for several species, out of which we used the formulas for Norway spruce (Picea abies), Scots pine (Pinus sylvestris), common beech (Fagus sylvatica), and pedunculate oak (Quercus petraea). The original functions were mathematically modified by introducing additional coefficients equal to 0 or 1 to obtain the same mathematical form for all cal-

Table 2. Green wood density $\left(D_{g w}\right)$ of individual species and their correction coefficients (I) used for the calculation of oven-dry biomass in individual tree compartments. The values are taken or derived from Klement et al. (2010), Miles \& Smith (2009), Požgaj et

\begin{tabular}{|c|c|c|c|c|c|c|c|}
\hline Tree species & $\mathrm{D}_{\mathrm{gw}}\left[\mathrm{kg} \mathrm{m}^{-3}\right]$ & $\mathrm{I}_{\text {bark }}$ & $\mathrm{I}_{\text {WUBT }}$ & Tree species & $\mathrm{D}_{\mathrm{gw}}\left[\mathrm{kg} \mathrm{m}^{-3}\right]$ & $\mathrm{I}_{\text {bark }}$ & $\mathrm{I}_{\text {wUBT }}$ \\
\hline Picea abies & 380 & 1.25 & 1.2 & Acer campestre & 500 & 1.13 & 1.1 \\
\hline Picea pungens & 380 & 1.25 & 1.2 & Acernegundo & 420 & 1.19 & 1.1 \\
\hline Picea mariana & 380 & 1.11 & 1.2 & Acersp. & 500 & 1.13 & 1.1 \\
\hline Picea glauca & 370 & 1.05 & 1.2 & Fraxinus excelsior & 570 & 0.91 & 1.1 \\
\hline Picea omorica & 380 & 1.25 & 1.2 & Fraxinus americana & 550 & 0.91 & 1.1 \\
\hline Picea engelmanni & 380 & 1.25 & 1.2 & Fraxinus angustifolia & 550 & 0.91 & 1.1 \\
\hline Picea sp. & 380 & 1.25 & 1.2 & Ulmus minor & 540 & 0.79 & 1.1 \\
\hline Abies alba & 370 & 1.37 & 1.2 & Ulmus glabra & 540 & 0.79 & 1.1 \\
\hline Abies grandis & 350 & 1.63 & 1.2 & Ulmus laevis & 540 & 0.79 & 1.1 \\
\hline Abies concolor & 370 & 1.51 & 1.2 & Robinia pseudoacacia & 660 & 0.44 & 1.1 \\
\hline Abies nordmanniana & 370 & 1.32 & 1.2 & Betula pendula & 520 & 1.13 & 1.1 \\
\hline Abies procera & 370 & 1.37 & 1.2 & Betula pubescens & 520 & 1.13 & 1.1 \\
\hline Abies sp. & 370 & 1.37 & 1.2 & Sorbus aucuparia & 531 & 1.00 & 1.1 \\
\hline Pseudotsuga menziesii & 450 & 0.98 & 1.2 & Sorbus torminalis & 564 & 1.00 & 1.1 \\
\hline Pinus sylvestris & 430 & 0.95 & 1.1 & Sorbus aria & 530 & 1.00 & 1.1 \\
\hline Pinus nigra & 430 & 0.95 & 1.1 & Juglans regia & 510 & 1.00 & 1.1 \\
\hline Pinus banksiana & 400 & 1.03 & 1.1 & Juglans nigra & 510 & 0.65 & 1.1 \\
\hline Pinus strobus & 340 & 1.38 & 1.1 & Platanus acerifolia & 460 & 1.30 & 1.1 \\
\hline Pinus cembra & 400 & 0.95 & 1.1 & Prunus avium & 470 & 1.34 & 1.1 \\
\hline Pinus contorta & 430 & 0.95 & 1.1 & Prunus serotina & 470 & 1.34 & 1.1 \\
\hline Pinus sp. & 430 & 0.95 & 1.1 & Pyrus communis & 564 & 1.00 & 1.1 \\
\hline Pinus mugo & 430 & 0.95 & 1.1 & Malus sylvestris & 610 & 0.82 & 1.1 \\
\hline Pinus rotundata & 430 & 0.95 & 1.1 & Tilia cordata & 440 & 1.50 & 1.1 \\
\hline Larix decidua & 450 & 0.65 & 1.1 & Tilia platyphyllos & 440 & 1.50 & 1.1 \\
\hline Larix sp. & 450 & 0.65 & 1.1 & Tilia tomentosa & 440 & 1.50 & 1.1 \\
\hline Taxus baccata & 600 & 1.00 & 1.2 & Alnus glutinosa & 417 & 1.51 & 1.1 \\
\hline Juniperus communis & 430 & 0.82 & 1.1 & Alnus incana & 355 & 1.51 & 1.1 \\
\hline Quercus robur & 550 & 1.00 & 1.1 & Alnus viridis & 355 & 1.51 & 1.1 \\
\hline Quercus robur slavonica & 550 & 1.00 & 1.1 & Populus tremula & 360 & 1.33 & 1.0 \\
\hline Quercus petraea & 550 & 1.00 & 1.1 & Populus alba & 360 & 1.33 & 1.0 \\
\hline Quercus rubra & 560 & 1.21 & 1.1 & Populus nigra & 360 & 1.33 & 1.0 \\
\hline Quercus pubescens & 550 & 1.00 & 1.1 & Populus sp. & 360 & 1.33 & 1.0 \\
\hline Quercus palustris & 580 & 1.03 & 1.1 & Populus $\times$ hybr. & 360 & 1.33 & 1.0 \\
\hline Quercus sp. & 550 & 1.00 & 1.1 & Salix caprea & 354 & 1.39 & 1.0 \\
\hline Quercus cerris & 550 & 1.00 & 1.1 & Salix alba, fragilis & 356 & 1.39 & 1.0 \\
\hline Fagus sylvatica & 570 & 1.20 & 1.1 & Aesculus hippocastanum & 330 & 1.52 & 1.1 \\
\hline Carpinus betulus & 650 & 0.95 & 1.1 & Castanea sativa & 400 & 1.25 & 1.1 \\
\hline Acerplatanoides & 500 & 1.13 & 1.1 & Ailanthus altissima & 460 & 0.98 & 1.1 \\
\hline Acerpseudoplatanus & 500 & 1.13 & 1.1 & & & & \\
\hline
\end{tabular}
al. (1993), Chmelař (1992), Meier (2013), Tümen \& Hafizoglu (2002). Correction index $I_{\text {bark }}$ represents the ratio between bark and wood density, correction index $I_{W U B T}$ represents the ratio between the wood densities of wood below and above $7 \mathrm{~cm}$. 
culated compartments in order to simplify the programming work. The function that we used for the calculation of biomass $(B)$ in the three compartments (green twigs, foliage, and stump+roots) has the following form:

$$
B=b_{1} \times\left(D B H+b_{2}\right)^{b_{3}} \times h^{b_{4}} \times b_{5}
$$

where:

$b_{1}-b_{5}$ are species specific regression coefficients.

Carbon stock $(C S)$ in tree compartmentswas estimated from the biomass amount $(B)$ in individual compartments multiplied by relative carbon content in biomass $(C C)$

$$
C S_{i}=B_{i} \times C C
$$

where:

$$
\begin{aligned}
B_{\mathrm{i}} & \text { - } \\
i & \text { biomass amount in } i^{\text {th }} \text { tree compartment, } \\
& \text { tree compartment as defined above: wood under } \\
& \text { bark with diameter equal to or above } 7 \mathrm{~cm} \text { (WUB), } \\
& \text { bark, wood under bark with diameter below } 7 \mathrm{~cm} \\
& \text { (WUBT), wood over bark with diameter equal to or } \\
& \text { above } 7 \mathrm{~cm} \text { (WOB), wood over bark with diameter } \\
& \text { below } 7 \mathrm{~cm} \text { (WOBT), green twigs (gtwigs), foliage } \\
& \text { (foliage), stump and roots (stump+roots). } \\
\text { CC - } & \text { relative carbon content in biomass. }
\end{aligned}
$$

Following "Good Practice Guidance for Land Use, Land-Use Change and Forestry" of Intergovernmental Panel on Climate Change (IPCC, 2003), we used a constant relative carbon content in biomass equal to 0.5 for all tree species.

Tree values are upscaled to a plot level by multiplying mean tree values per species with the respective number of trees per species and summing the species plot values together:

$$
X_{\text {plot }}=\Sigma X_{\text {species }} \times N_{\text {species }}
$$

where:

$X$ - is any estimate for a mean tree (e.g. volume, biomass, carbon),

$N$ - is number of trees of a particular species on a plot.

These plot values were further processed to obtain summary information about carbon stock at national and regional levels. The Czech Republic is divided into 14 administrative units called regions (kraj in Czech lan- guage). Table 3 presents their area together with their forest area and forest cover. The data from this table were used for the calculation of carbon density at national and regional levels.

The summary information on carbon stock at national and regional levels was calculated using the so called "Ratio of Means" method (Cochran 1977). It means that from the sampled data we first derived the values per hectare $\left(\mathrm{X}_{\mathrm{ha}}\right)$, which were afterwards multiplied with the total forest area $\left(\mathrm{A}_{\text {tot }}\right)$ of the country or a region:

$$
\begin{aligned}
& X_{h a}=\frac{\sum_{i=1}^{n} X_{i}}{\sum_{i=1}^{n} A_{i}} \\
& X_{t o t}=X_{h a} \times A_{t o t}
\end{aligned}
$$

The standard error of the mean was calculated using the model for cluster sampling (Cochran 1977). For the presentation of the results we created 6 groups of tree species named after the most common genera in the tree species composition of Czech forests (Štěrba \& Jankovská 2007): Spruce, Pine, Beech, Larch, Oaks, and Others. The spruce group consists of all spruce species occurring in the forests of the Czech Republic: Picea abies, Picea pungens, Picea mariana, Picea glauca, Picea omorica, Picea engelmanni, Picea sp. Similarly, the pine group contains all pine species: Pinus sylvestris, Pinus nigra, Pinus banksiana, Pinus strobus, Pinus cembra, Pinus contorta, Pinus sp., Pinus mugo, Pinus rotundata, Larix decidua and Larix sp. form Larch group. In the group of Oaks there are Quercus robur, Quercus robur slavonica, Quercus petraea, Quercus rubra, Quercus pubescens,

\begin{tabular}{|c|c|c|c|c|c|c|}
\hline \multirow{2}{*}{$\begin{array}{c}\text { Code } \\
\text { of region }\end{array}$} & \multirow{2}{*}{ Name of region } & Total area $^{1}$ & Share in the area of CR & Forest area $^{2}$ & Share on total forest cover of CR & Relative forest cover ${ }^{3}$ \\
\hline & & [ha] & [\%] & [ha] & & [\%] \\
\hline PHA & Hlavní město Praha & 49,608 & 0.63 & 5,021 & 0.17 & 10.12 \\
\hline STČ & Středočeský kraj & $1,101,464$ & 13.97 & 338,251 & 11.70 & 30.71 \\
\hline JHČ & Jihočeský kraj & $1,005,731$ & 12.75 & 412,434 & 14.27 & 41.01 \\
\hline PLK & Plzeňský kraj & 756,107 & 9.59 & 324,932 & 11.24 & 42.97 \\
\hline KVK & Karlovarský kraj & 331,453 & 4.20 & 159,425 & 5.51 & 48.10 \\
\hline ULK & Ústecký kraj & 533,489 & 6.76 & 178,294 & 6.17 & 33.42 \\
\hline LBK & Liberecký kraj & 316,300 & 4.01 & 152,300 & 5.27 & 48.15 \\
\hline HKK & Královéhradecký kraj & 475,824 & 6.03 & 166,868 & 5.77 & 35.07 \\
\hline PAK & Pardubický kraj & 451,860 & 5.73 & 146,284 & 5.06 & 32.37 \\
\hline VYS & Kraj Vysočina & 692,555 & 8.78 & 219,003 & 7.58 & 31.62 \\
\hline JHM & Jihomoravský kraj & 706,674 & 8.96 & 206,442 & 7.14 & 29.21 \\
\hline OLK & Olomoucký kraj & 515,892 & 6.54 & 186,566 & 6.45 & 36.16 \\
\hline ZLK & Zlínský kraj & 396,376 & 5.03 & 180,062 & 6.23 & 45.43 \\
\hline MSK & Moravskoslezský kraj & 553,505 & 7.02 & 214,924 & 7.43 & 38.83 \\
\hline $\mathrm{CR}$ & Czech Republic in total & $7,886,838$ & 100.00 & $2,890,805$ & 100.00 & 36.65 \\
\hline
\end{tabular}
Quercus palustris, Quercus sp., Quercus cerris. The beech group contains only Fagus sylvatica. The group of Others comprises Abies alba, Abies grandis, Abies concolor, Abies nordmanniana, Abies procera, Abies sp., Pseudotsuga menziesii, Taxus baccata, Juniperus communis, other conifers, Carpinus betulus, Acer platanoides, Acer pseudoplatanus, Acer campestre, Acer negundo, Acer sp., Fraxinus excelsior, Fraxinus americana, Fraxinus angustifolia, Ulmus minor, Ulmus glabra, Ulmus laevis, Robinia pseudoacacia, Betula pendula, Betula pubescens, Sorbus aucuparia, Sorbus torminalis, Sorbus aria, Juglans regia, Juglans nigra, Platanus acerifolia, Prunus avium, Prunus

Table 3. The basic information about the size and forest area of regions of the Czech Republic.

${ }^{1}$ ČÚZK (2005); ${ }^{2}$ calculated from the relative forest cover; ${ }^{3}$ calculated from NFI, http://nil.uhul.cz/. 
serotina, Pyrus communis, Malus sylvestris, Tilia cordata, Tilia platyphyllos, Tilia tomentosa, Alnus glutinosa, Alnus incana, Alnus viridis, Populus tremula, Populus alba, Populus nigra, Populus sp., Populus $\times$ hybr., Salix caprea, Salix alba, Salix fragilis, Aesculus hippocastanum, Castanea sativa, Ailanthus altissima, and other broadleaved species.

\section{Results}

\subsection{Forest carbon at regional levels}

Since the regions, i.e. administrative units, in the $\mathrm{Czech}$ Republic are rather heterogeneous territories in both size (area) and forest cover (Table 3), we examined their carbon stock in the merchantable tree forest cover (Fig. 2), carbon density, i.e. carbon amount per unit area (expressed per ha of forests or per ha of the total territory; Fig. 3 and 4, respectively), the relative carbon amount fixed in merchantable forest trees in a specific region calculated as a proportion of the whole country carbon stock (Fig. 5). Besides, we analysed the carbon

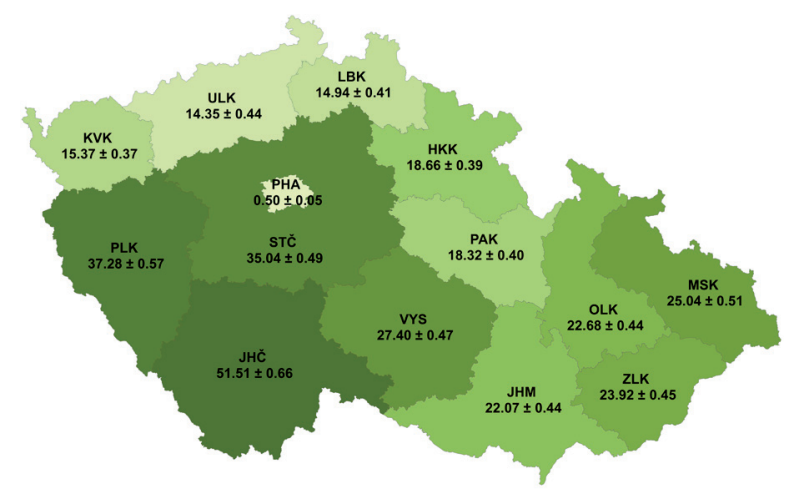

Fig. 2. Total carbon amount (mill. t) fixed in the forest cover of the Czech Republic represented by living trees with diameter equal or above $7 \mathrm{~cm}$ growing in the forests by the regions. Values represent mean \pm standard error.

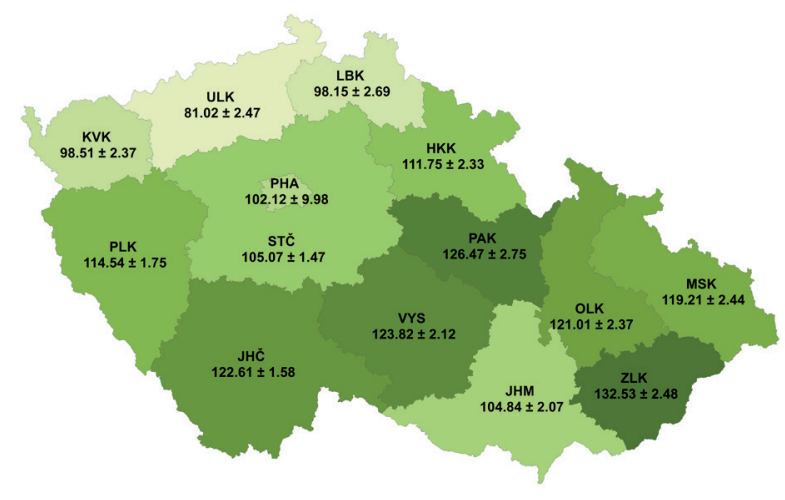

Fig. 3. Carbon amount fixed in the living trees with diameter equal or above $7 \mathrm{~cm}$ growing in the forests of the Czech Republic per ha of the region forest area $\left(\mathrm{tC} \mathrm{ha}^{-1}\right)$ by the regions. Values represent mean \pm standard error. stock also with regard to the number of inhabitants and gross domestic product by calculating forest tree carbon per capita (Fig. 6) and per gross domestic product of the regions (Fig. 7). All presented figures clearly show the differences in all carbon stock parameters between the regions. However, the correlation analyses between the regional carbon stocks and population density or gross domestic product did not reveal any significant trends in the carbon stock in relation to the demographic and economic indicators.

\subsection{Forest carbon stock at a country level}

The total amount of carbon stored in merchantable forest trees of the Czech Republic was over 327 mill. $t$ (Table 4). It is about $113 \mathrm{t}$ of carbon per ha of forests and almost $32 \mathrm{t}$ of carbon per capita. If we consider tree species, the greatest amount of carbon (160 mill. t, i.e. $49 \%$ of the total amount) was fixed in Spruce group, followed by Pine group (50 mill. t; 15.4\%), Others (45 mill. t; 13.9\%), Beech (30 mill. t; 9.3\%), Oaks (25 mill. t; 7.7\%) and Larch (15 mill. t; 4.7\%). Conifer-

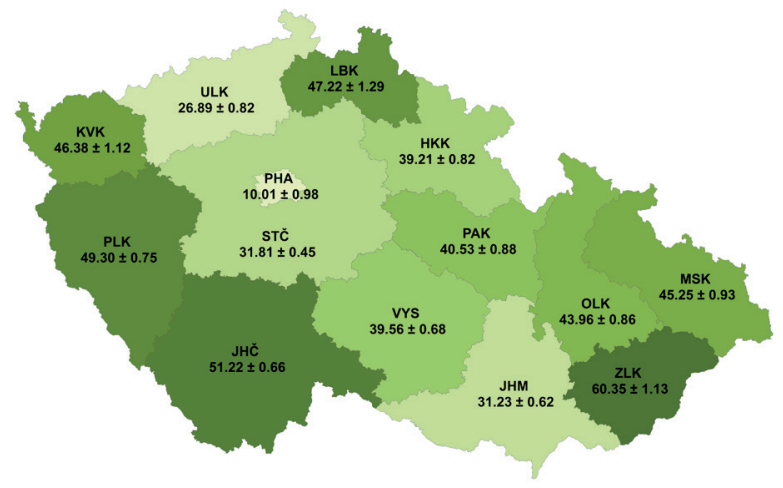

Fig. 4. Carbon amount fixed in the living trees with diameter equal or above $7 \mathrm{~cm}$ growing in the forests of the Czech Republic $(\mathrm{t})$ per ha of the region. Values represent mean \pm standard error.

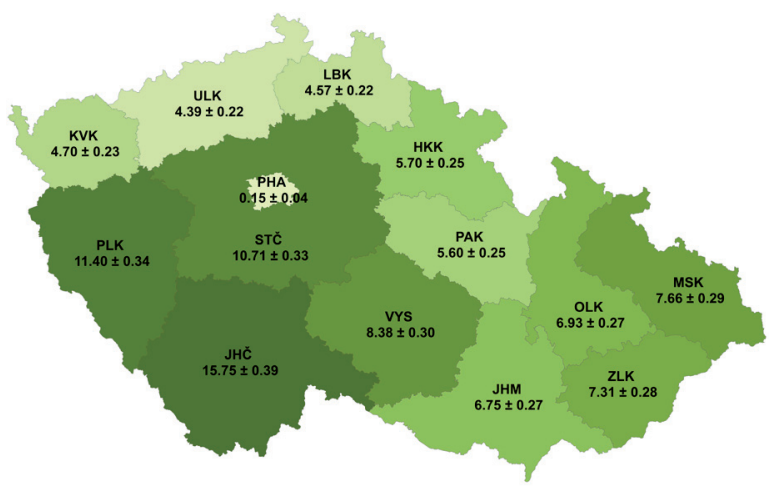

Fig. 5. Relative contribution (\%) of the regions to the total carbon amount fixed in the forest cover of the Czech Republic represented by the living trees with diameter equal or above $7 \mathrm{~cm}$ growing in the forests of the Czech Republic. Values represent mean \pm standard error. 


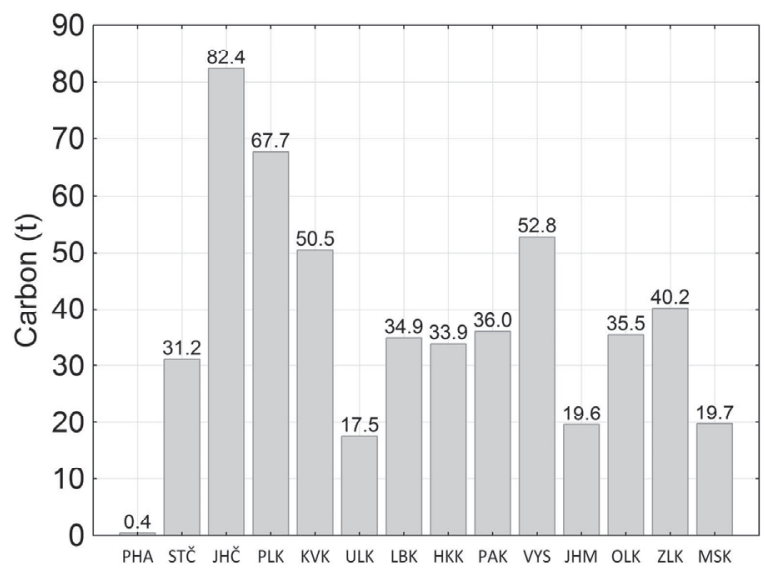

Fig. 6. Carbon amount $(\mathrm{t})$ fixed in the forest cover of the regions expressed per capita.

ous species fixed about 230 mill. $t$ of carbon (70.4\%) in their biomass, and broadleaved species $97 \mathrm{t}$ (29.6\%) of carbon. Considering tree compartments irrespective of tree species (Table 5), wood $\geq 7 \mathrm{~cm}$ contributed to the total carbon amount most (58.1\%), followed by stump and roots (19.0\%), stembark (8.8\%), wood $<7 \mathrm{~cm}(6.2 \%)$, green twigs (4.8\%) and finally foliage (3.2\%).

The combination of contribution of specific tree compartments of main tree species may provide information about the quantity of carbon fixed in tree biomass for a short or a long period. While carbon in woody parts (branches, stem, coarse roots) is fixed for a long period, carbon in foliage rotates fast: annually in the case of deciduous species, and once per approx. 2.5 years in the case of pine or once per 5 years in the case of spruce. This different foliage rotation is reflected in contrasting contribution of tree species in carbon amount in foliage and annual foliage fall, which was estimated from the NFI

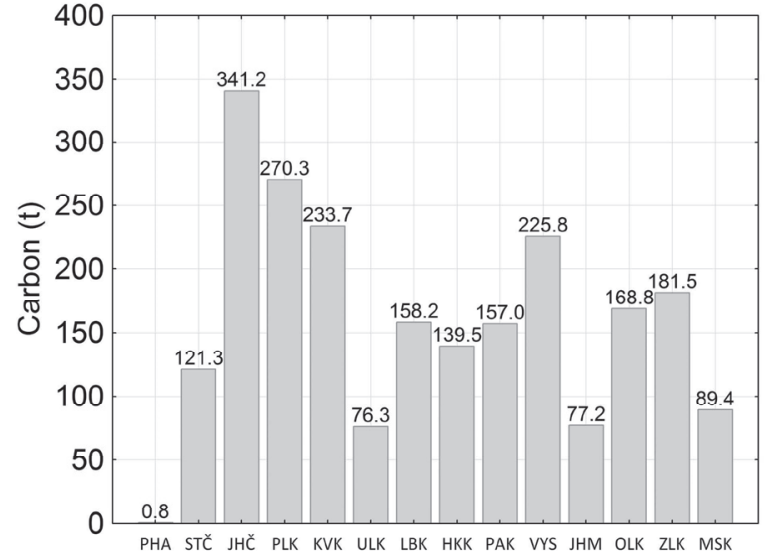

Fig. 7. Carbon amount (t) fixed in the forest cover expressed per gross domestic product of the region (in millions of Czech Crowns).

data using the above mentioned assumptions of foliage rotation (Fig. 8). At a country level, as much as 10 million $t$ of carbon was fixed in the foliage at the time of the first national forest inventory (Table4). Spruce, as a dominant tree species, contributed to as much as $73.2 \%$ of the total carbon in the foliage of all tree species (Table 5). On the contrary, the contribution of the main deciduous tree species (beech, oak and larch together) to the total foliage carbon stock was only $8.6 \%$ (Table 5).

We estimated that out of the total 10 mill. t of carbon in foliage, approximately 3.6 mill. t is annually "lost" from the living tree biomass due to the leaf fall. The contribution of spruce to the annual carbon loss by leaf fall was only $41.8 \%$, while the contribution of the main deciduous tree species (beech, oak and larch together) to leaf fall was as much as $24.4 \%$ (Fig. 8 ).

Table 4. Total carbon amount (mill. $t$ of carbon) in the forest cover of the Czech Republic distributed among the tree species groups and tree compartments.

\begin{tabular}{|c|c|c|c|c|c|c|c|}
\hline \multirow{2}{*}{ Compartment } & \multicolumn{7}{|c|}{ Carbon amount [mill. t] by tree species group (mean \pm standard error) } \\
\hline & Spruce & Pine & Beech & Larch & Oaks & Others & Together \\
\hline Green twigs & $11.05 \pm 0.11$ & $1.78 \pm 0.04$ & $0.51 \pm 0.01$ & $0.44 \pm 0.01$ & $0.53 \pm 0.01$ & $1.33 \pm 0.02$ & $15.64 \pm 0.10$ \\
\hline Foliage & $7.56 \pm 0.08$ & $1.09 \pm 0.02$ & $0.30 \pm 0.01$ & $0.27 \pm 0.01$ & $0.31 \pm 0.01$ & $0.78 \pm 0.01$ & $10.32 \pm 0.07$ \\
\hline Wood $<7 \mathrm{~cm}$ & $7.55 \pm 0.08$ & $2.92 \pm 0.06$ & $2.72 \pm 0.08$ & $0.55 \pm 0.02$ & $1.96 \pm 0.06$ & $4.48 \pm 0.09$ & $20.20 \pm 0.11$ \\
\hline Wood $\geq 7 \mathrm{~cm}$ & $97.88 \pm 1.09$ & $27.19 \pm 0.56$ & $19.13 \pm 0.60$ & $7.93 \pm 0.24$ & $13.62 \pm 0.41$ & $24.41 \pm 0.51$ & $190.16 \pm 1.12$ \\
\hline Stem bark & $12.68 \pm 0.13$ & $3.12 \pm 0.06$ & $2.31 \pm 0.07$ & $1.59 \pm 0.05$ & $4.26 \pm 0.12$ & $4.67 \pm 0.09$ & $28.64 \pm 0.16$ \\
\hline Stump and roots & $23.73 \pm 0.24$ & $14.19 \pm 0.28$ & $5.52 \pm 0.17$ & $4.42 \pm 0.13$ & $4.66 \pm 0.13$ & $9.60 \pm 0.20$ & $62.11 \pm 0.34$ \\
\hline Whole tree & $160.45 \pm 1.72$ & $50.30 \pm 1.01$ & $30.49 \pm 0.93$ & $15.22 \pm 0.45$ & $25.34 \pm 0.74$ & $45.28 \pm 0.90$ & $327.07 \pm 1.74$ \\
\hline
\end{tabular}

Table 5. Relative carbon content (\%) in tree compartments of individual tree species groups in the Czech Republic.

\begin{tabular}{|c|c|c|c|c|c|c|c|}
\hline \multirow{2}{*}{ Compartment } & \multicolumn{7}{|c|}{ Relative carbon content in the Czech Republic [\%] by tree species group (mean \pm standard error) } \\
\hline & Spruce & Pine & Beech & Larch & Oaks & Others & Together \\
\hline Green twigs & $6.88 \pm 0.27$ & $3.55 \pm 0.20$ & $1.66 \pm 0.14$ & $2.91 \pm 0.18$ & $2.11 \pm 0.15$ & $2.94 \pm 0.18$ & $4.78 \pm 0.23$ \\
\hline Foliage & $4.71 \pm 0.23$ & $2.17 \pm 0.16$ & $0.97 \pm 0.11$ & $1.81 \pm 0.14$ & $1.23 \pm 0.12$ & $1.73 \pm 0.14$ & $3.16 \pm 0.19$ \\
\hline Wood $<7 \mathrm{~cm}$ & $4.71 \pm 0.23$ & $5.81 \pm 0.25$ & $8.93 \pm 0.31$ & $3.63 \pm 0.20$ & $7.74 \pm 0.29$ & $9.89 \pm 0.32$ & $6.17 \pm 0.26$ \\
\hline Wood $\geq 7 \mathrm{~cm}$ & $61.00 \pm 0.52$ & $54.06 \pm 0.53$ & $62.76 \pm 0.52$ & $52.12 \pm 0.54$ & $53.74 \pm 0.53$ & $53.90 \pm 0.53$ & $58.14 \pm 0.53$ \\
\hline Stem bark & $7.90 \pm 0.29$ & $6.21 \pm 0.26$ & $7.58 \pm 0.28$ & $10.48 \pm 0.33$ & $16.80 \pm 0.40$ & $10.32 \pm 0.33$ & $8.76 \pm 0.30$ \\
\hline Stump and roots & $14.79 \pm 0.38$ & $28.21 \pm 0.48$ & $18.10 \pm 0.41$ & $29.05 \pm 0.49$ & $18.37 \pm 0.42$ & $21.21 \pm 0.44$ & $18.99 \pm 0.42$ \\
\hline Whole tree & 100 & 100 & 100 & 100 & 100 & 100 & 100 \\
\hline
\end{tabular}




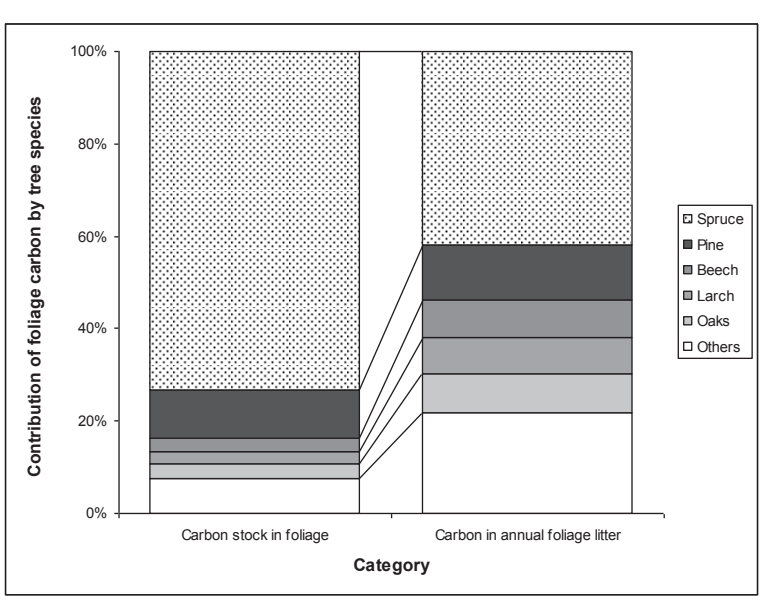

Fig. 8. Contribution of foliage carbon by tree species to total carbon stock in foliage and total carbon in annual leaf fall in the Czech Republic.

\section{Discussion}

The knowledge on biomass (carbon) allocation in trees is important for understanding and quantification of processes related to carbon sequestration and cycling in forest ecosystems (Dickson 1989). Quantifications of carbon fixed in forest tree biomass with regard to the contribution of individual tree compartments and species at a variety of scales (regional, national, and continental levels) are necessary to assess the importance of forests for the mitigation of climate change. For the thorough monitoring of forest carbon stocks the estimation of carbon amount fixed in all tree compartments is required, as forest management and harvesting activities affect not only the economically interesting biomass compartments, but the whole carbon cycle. However, many studies report only the information about economically interesting biomass compartments, i.e. usually stem or merchantable timber (Wutzler et al. 2008), which contributes to more than a half of the whole tree biomass, e.g. in our case $58 \%$ of biomass carbon was sequestered in the timber with diameter equal to or greater than $7 \mathrm{~cm}$. Similarly Wutzler et al. (2011) estimated that stem biomass contributed to $60 \%$ of the total tree carbon stock of a German forest.

The presented study attempted to overcome this shortage by covering all living tree compartments including branches, leaves and belowground root biomass. Our results showed that altogether approximately 327 mill. $t$ of carbon is fixed in the tree biomass of the Czech forests, which is about $113 \mathrm{t}$ of carbon per hectare of forests, or 42 t of carbon per hectare of the whole-country area. The total carbon stock corresponds to 322 mill. $t$, which is the official statistics for the year 2000 published in Forest Europe (2015). The results are slightly higher than the estimates of biomass in Czech forests using allometric relationships, which indicated 586 mill. t of tree biomass (i.e. 293 mill. $t$ of carbon) allocated in the forests of the
Czech Republic or 213 t of biomass (i.e. $106 \mathrm{t}$ of carbon) per hectare (Kučera et al. 2014). The differences between the estimates result from the different subset of trees, different approaches of calculating the biomass and different grouping of tree species. We based our calculations of stem wood biomass on the volume equations compiled by Petráš \& Pajtík (1991), because they were derived for 11 different tree species using data from several thousands of sample trees per species (Table 1). On the other hand, Kučera et al. (2014) used allometric relations for four different tree species, which were based on a smaller number of sample trees. For instance Wirth et al. (2004) used the information about 688 sample trees, but Cienciala et al. (2006, 2008) and Vejpustková et al. (2013) used data from less than one hundred sample trees. The problem with small samples has already been discussed by e.g. Brown et al. (1999). The impact of the applied equations on the biomass estimates has been pointed out by several studies, e.g. Neumann et al. (2016). Thus, we assume that the accuracy of the results can be higher if the above-mentioned volume equations derived from large samples collected at the investigated territory together with the available data from NFI (e.g. information about tree species) are applied. In addition, volume equations are frequently used and well understood methods in forestry because of the long-term research in this field. In the compilation of the method we tried to account for all the important factors in biomass estimation, and this gave us a picture of the currently available information. Wood density may be the weak point of the suggested method, as it is known to change with site conditions, tree position within a stand, and position on a tree. Nevertheless, the values of wood density given in Table 2 were taken from national or Central European publications if possible, and hence, they should represent the Czech forests better than e.g. constant values given in IPCC Guidelines.

A similar average hectare value of carbon stock in forests (110 t per ha of forests) was found by Brunner \& Godbold (2007) for temperate central European forests. Likewise, in Germany and Slovakia forest carbon stock density in tree biomass was $104 \mathrm{t}$ (Dieter \& Elsasser 2002) and 110 t of carbon per hectare, (MA SR, 2016) respectively. However, the countries had contrasting carbon amounts when expressed per capita, since the value for Slovakia was 30\% higher than for the Czech Republic. If we consider the European Union (EU) level, the Czech Republic contributes to about $3 \%$ of carbon fixed in forest tree biomass, although its share in the EU territory is only 1.8\% (Forest Europe 2015; MA CR 2016).

Even though the average Czech carbon stock density in forest tree biomass per spatial unit exceeded the European average, we revealed high regional differences within the country. Those are related to both forest area and forest hectare stock. Our analyses on forest tree carbon stock per hectare of forests and per hectare of region suggested that nearly $1 / 6$ of all carbon was present in Jihočeský kraj. The region is typical with large forest 
complexes and high share of spruce growing mainly in the southern part of the region (Šumava and Novohradské hory). Ústecký kraj contributed to forest biomass carbon least, whether it was expressed as total carbon amount per region or as carbon amount per hectare of forests or per hectare of the region. These results are in accordance with Kučera et al. (2014), who also found the highest and the lowest amount of tree biomass in Jihočeský and Ústecký kraj, respectively. The performed correlation analyses between the regional carbon stocks and demographic and economic parameters revealed positive trends with both population density and gross domestic product, but the relationships were not significant (not shown). This can be explained by the regional differences in carbon stock resulting from their long-term historical development and different natural conditions, which have been limiting factors for settlements or agricultural activities (hilliness, wetlands, etc.), and later also to premeditated exertion of human being (Palmer et al. 2008). Since recently the Czech Republic proclaimed national rural development programmes (co-financed by EU) including afforestation (Forest Europe 2015) as a key measure for the implementation of policy on forest carbon, continuously increasing forest area might be anticipated in most regions. The values representing individual regions together with the information about site and terrain conditions and past development of forests can be used to estimate the carbon sequestration capacity of individual regions of the country.

Spruce is the main tree species in the Czech Republic. It covers about $50 \%$ of the total forest area of the Czech Republic (MACR 2016). Congruously to this figure, our calculations demonstrated that this tree species contributed to $49 \%$ of the total forest tree biomass of the country. Moreover, the results showed that the ratio of spruce foliage to its total biomass was higher than for other species $(4.7 \%$ for spruce against $2.2 \%, 1.0 \%, 1.8 \%$ and $1.2 \%$ for pine, beech, larch and oaks, respectively) due to its longer time span of foliage. The opposite situation was observed in the case of shed foliage (annual leaf fall), its proportion to the total tree biomass was in the case of spruce as well as pine only $0.9 \%$, while in the case of beech, larch and oaks it was $1.0 \%, 1.8 \%$ and $1.2 \%$, respectively. These values indicate that spruce trees "lose" lower fraction of carbon fixed in total tree biomass via leaf fall than the deciduous species. This spruce characteristic may together with its high wood productivity (Šebík \& Polák 1990) be an advantage of this species in carbon sequestration in comparison with other tree species. On the other hand, spruce is very sensitive to climate change, especially if it is located at lower elevations, i.e in its ecological suboptimum conditions. Due to this, there is an increased risk of physiological stress caused by drought, more frequent damages caused by abiotic and biotic damages (Lindner et al. 2010), and consequently the loss of the accumulated carbon from the living biomass.

The summary of our results shows that although the
Czech Republic covers a small territory in Europe, its carbon stock in forest biomass per hectare exceeded the EU average. Since the country has committed to support afforestation as a part of its national rural developmental program, it can be expected that the importance of forests in carbon sequestration processes will increase.

Carbon sequestration capacity of the Czech forests can be strengthened by promoting forest protection (prevention to wind damage, forest fires, bark beetle outbreaks) as well conservation of forests grown on wetlands. State policy should concentrate on the sustainable development of stable, diverse and productive forests (see for instance Jandl et al. 2007; Nabuurs et al. 2008; Ashton et al. 2012). A forest management map of European forests developed by Hengeveld et al. (2012) defining the most suitable forest management alternative at a $1 \mathrm{~km}$ resolution on the base of 8 biotic, abiotic, socioeconomic, and political factors suggested that there is a great potential of Czech forestry to apply close-to-nature forest management as defined by Duncker et al. (2012). Although this type of forest management is frequently considered as the best approach with regard to future climate change, it might not always result in the increase of carbon stock because the adaptive mechanisms of this management identified by Brang et al. (2014) include keeping low average volume stocks, and hence also low carbon stocks of forests. Since the increase of carbon sequestration is one of the primary climate change mitigation measures (Sheikh et al. 2014), a consensus between the adaptation to climate change and its mitigation must be solved.

Bellassen \& Luyssaert (2014) suggested that from the point of carbon sequestration forest management aimed at the increase of forest stocks and timber harvest should always be prioritised. Unlike some adaptation measures, the effect of which is only assumed because it could not have been proven yet, the increase in volume will always increase carbon stock. The picture becomes more complex if we account for the post-growth processes. Harvesting reduces forest cover and thus the amount of carbon stored in forests, but using the harvested wood for construction purposes and long-term wooden products prolongs the time of carbon fixation (Raši et al. 2015). In addition, different wood extraction technologies and post-harvest treatments, e.g. slash burning, also affect carbon stock of the stand and the whole carbon cycle within the ecosystem. Hence, the information about the carbon stock in individual compartments together with the information about the applied management and extraction technologies can provide us with the estimates of future carbon stock. Apart from that, forest management and harvesting methods also affect soil properties including soil carbon, which is very sensitive to aboveground changes. Thus, the whole picture of the carbon cycle including the life cycle of wood products needs to be accounted for. By applying the so called 'win-win' or 'no-regret' strategies we can save some time until we 
widen and/or justify our knowledge about forest behaviour in changing climate (Bellassen \& Luyssaert 2014), because some projections of forest development under climate change indicate increased mortality followed by larger carbon emissions that can exceed its sequestration (Somogyi 2016).

\section{Conclusions}

The knowledge on biomass (carbon) allocation in trees is important for understanding and quantification of processes related to carbon sequestration and cycling in forest ecosystems. The presented study attempted to cover all living tree compartments including branches, leaves and belowground biomass. Our results showed that altogether approximately 327 mill. $t$ of carbon is fixed in the tree biomass of the Czech forests, which is about 113 t of carbon per hectare of forests. Hence, the Czech Republic contributes to about $3 \%$ of carbon fixed in forest tree biomass of the EU, although its share in the EU territory is only $1.8 \%$. Spruce is the main tree species group in the Czech Republic. Our calculations demonstrated that this tree species group contributed to $49 \%$ of the total forest tree biomass of the country. Moreover, the results showed that the ratio of spruce foliage to its total biomass was higher than for other species due to its longer time span of foliage. Nearly 1/6 of all carbon sequestered in forests was present in Jihočeský kraj. To strengthen carbon sequestration capacity of the Czech forests, forestry should apply win-win forest management strategies. In addition, forest protection against disturbance factors as well as conservation of forests grown on wetlands (e.g. the Šumava region in Jihočeský kraj) would be promoted.

\section{Acknowledgments}

This work was supported by the 7. RP project FORest Management Options for enhancing the MITigation potential of European forests (FORMIT) and in part by the Slovak Research and Development Agency under contracts APVV-0268-10, APVV14-0086, and $A P V V-15-0265$.

\section{References}

Andronache, I., Ahammer, H., Ciobotaru, A., Drăghici, C., Diaconu, D. C., Fensholt, R., et al., 2017: Assessment of Textural Differentiations in Forest Resources in Romania Using Fractal Analysis. Forests, 8:54; doi:10.3390/f8030054.

Ashton, M. S., Tyrell, M. L., Spalding, D., Gentry, B., 2012: Managing Forest Carbon in a Changing Climate. Springer, Dordrecht, $414 \mathrm{p}$.

Bellassen, V., Luyssaert, S., 2014: Carbon sequestration: Managing forests in uncertain times. Nature, 506:153-155.
Brang, P., Spathelf, P., Larsen, J. B., Bauhus, J., Boncčìna, A., Chauvin et al., 2014: Suitability of close-to-nature silviculture for adapting temperate European forests to climate change. Forestry, 87:492-503.

Brown, S., 1997: Estimating Biomass and Biomass Change of Tropical Forests: a Primer. FAO Forestry Paper 134, FAO, United Nations, Rome.

Brown, S. L., Schroeder, P., Kern, J. S., 1999: Spatial distribution of biomass in forests of the eastern USA. Forest Ecology and Management, 123:81-90.

Brown, S., 2002: Measuring carbon in forests: current status and future challenges. Environmental Pollution, 116:363-372.

Brunner, I., Godbold, D., 2007: Tree roots in changing world. Journal of Forest Research, 12:78-82.

Cienciala, E., Apltauer, J., Exnerová, Z., Tatarinov, F., 2008: Biomass functions applicable to oak trees grown in Central-European forestry. Journal of Forest Science, 54:109-120.

Cienciala, E., Cerny, M., Tatarinov, F., Apltauer, J., Exnerova, Z., 2006: Biomass functions applicable to Scots pine. Trees - Structure and Function, 20:483-495.

Cochran, G. V., 1977: Sampling Techniques. John Viley and Sons, Inc., 428 p.

Crespo Cuaresma, J., Danylo, O., Fritz, S., McCallum, I., Obersteiner, M., See, L., Walsh, B., 2017: Economic Development and Forest Cover: Evidence from Satellite Data. Nature Scientific Reports 7, Article number: 40678, doi:10.1038/srep40678.

Cvitanovic, M., Blackburn, G. A., Jepsen, M. R., 2016: Characteristics and drivers of forest cover change in the post-socialist era in Croatia: evidence from a mixed-methods approach. Regional Environmental Change, 16:1751-1763.

ČÚZK, 2005: Statistická ročenka půdního fondu České republiky. Souhrnné výstupy ze souboru popisných informací katastru nemovitostí České republiky se stavem ke dni 31. prosince 2004. Praha, Český úřad zeměměřický a katastrální, 48 p.

Dieter, M., Elsasser, P., 2002: Carbon Stocks and Carbon Stock Changes in the Tree Biomass of Germany's Forests. Forstwissenschaftliches Centralblatt, 121:195-210.

Dickson, R. E., 1989: Carbon and nitrogen allocation in trees. Annals of Forest Science, 46:631-647.

Drexhage, M., Colin, F., 2001: Estimating root system biomass from breast-height diameters. Forestry, 74:491-497.

Duncker, P. S., Barreiro, S. M., Hengeveld, G. M., Lind, T., Mason, W. L., Ambrozy et al., 2012: Classification of forest management approaches: a new conceptual framework and its applicability to European forestry. Ecology and Society, 17:51.

Forest Europe, 2015: State of Europe's Forests. Forest Europe Liaison Unit Madrid, Madrid, 312 p. 
Helmisaari, H. S., Makkonen, K., Kellomäki, S., Valtonen, E., Mälkönen, E., 2002: Below- and aboveground biomass, production and nitrogen use in Scots pine stands in eastern Finland. Forest Ecology and Management, 165:317-326.

Hengeveld, G. M., Nabuurs, G. J., Didion, M., van den Wyngaert, I., Clerkx, A. P. P. M., Schelhaas, M. J., 2012: A forest management map of European forests. Ecology and Society, 17:53.

Chmelař, T., 1992: Variability of the conventional wood density of spruce branches in dependence on the position of branches in crown. Lesnictví, 38:127-135.

IPCC (Intergovernmental Panel on Climate Change), 2003: Good Practice Guidance for Land Use, LandUse Change and Forestry. In: Penman, J. et al. (eds.), Institute for Global Environmental Strategies (IGES).

Jandl, R., Lindner, R., Vesterdal, L., Bauwens, B., Baritz, R., Hagedorn, F. et al., 2007: How strongly can forest management influence soil carbon sequestration? Geoderma, 137:253-268.

Janssens, I., Freibauer, A., Schilamadinger B., Ceulemans, R., Ciais P., Dolman A. J., 2005: The carbon budget of terrestrial ecosystems at country-scale - a European case study. Biogeosciences, 2:15-26.

Keenan, R. J., Reams, G. A., Achard, F., de Freitas, J. V., Grainger, A., Lindquist, E., 2015: Dynamics of global forest area: results from the FAO global forest resources assessment 2015. Forest Ecology and Management, 352:9-20.

Klement, I., Réh, R., Detvaj, J., 2010: Základné charakteristiky lesných drevín - spracovanie drevnej suroviny v odvetví spracovania dreva. Zvolen, NLC, $82 \mathrm{p}$.

Kučera, M., Adolt, R., Kohn, I., Piškytlová, K., Kratěna, L., Fejfar, J. et al., 2016: Výstupy Národní inventarizace lesů uskutečněné v letech 2011-2015. Lesnická práce, 95, supplement No. 12, Nadzemní biomasa, 8 p.

Kučera, M., Adolt, R., Pikula, T., 2014:Závěrečná zpráva projektu "Framework contract for the provision of forest data and services in support to the European Forest Data Centre" Reference: 2012/ S 78-127532 of 21/04/2012: Use of National Forest Inventories data to estimate biomass in the European Forests Country Report Czech Republic.

Lindner, M., Karjalainen, T., 2007: Carbon inventory methods and carbon mitigation potentials of forests in Europe: a short review of recent progress. European Journal of Forest Research, 126:149-156.

Lindner, M., Maroschek, M., Netherer, S., Kremer, A., Barbati, A., Garcia-Gonzalo, J. et al., 2010: Climate change impacts, adaptive capacity, and vulnerability of European forest ecosystems. Forest Ecology Management, 259:698-709.

Li, Y., Viña, A., Yang, W., Chen, X., Zhang, J., Ouyang, Z. et al., 2013: Effects of Conservation Policies on Forest Cover Change in Giant Panda Habitat Regions, China. Land Use Policy, 33:42-53.
Loehle, C., 1987: Tree life history strategies: the role of defenses. Canadian Journal of Forest Research, 18:209-222.

MacDicken, K. G., 2015. Global Forest Resources Assessment 2015: what, why and how? Forest Ecology and Management, 352:3-8.

Meier, E., 2013: The Wood Database - Lumber Identification (Hardwoods). Accessed online 06.03.2017: http://www.wood-database.com.

Miles, P. D., Smith, W. B., 2009: Specific gravity and other properties of wood and bark for 156 tree species found in North America. Research Note NRS-38. Newtown Square, PA: U.S. Department of Agriculture, Forest Service, Northern Research Station. 35.

MA CR, 2016: Information on Forestry and Forestry in the Czech Republic by 2015. Prague, Ministry of Agriculture of the Czech Republic, 29 p.

MASR, 2016: Report on Forestry in the Slovak Republic per year 2016. Bratislava, Ministry of Agriculture of the Slovak Republic, 76 p.

Nabuurs, G. J., Thürig, E., Heidema, N., Armolatis, K., Biber, P. Cienciala, E. et al., 2008: Hotsposts of the European forests carbon cycle. Forest Ecology and Management, 256:194-200.

Neumann, M., Moreno, A., Mues, V., Härkönen, S., Mura, M., Bouriaud, O. et al., 2016: Comparison of carbon estimation methods for European forests. Forest Ecology and Management, 361:397-420.

Palmer, R. R., Molton, J., Kamer, L., 2008: A History of the Modren World. McGraw Hill, New York, 458 p.

Petráš, R., Košút, M., Oszlányi, J., 1985: Leaf biomass of trees in spruce, pine and beech. Lesnícky časopis, 31:121-136.

Petráš, R., Pajtík, J., 1991: Sústava česko-slovenských objemových tabuliek drevín. Lesnícky časopis, 37:49-56.

Petráš, R., 1986: Mathematical model of stem shape. Lesnícky časopis, 32:223-236.

Petráš, R., 1989: Mathematical model of stem shape of coniferous tree species. Lesnictví, 35:867-878

Petráš, R., 1990: Mathematical model of stem shape of broadleaved tree species. Lesnícky časopis, 36:231241.

Petráš, R., 1984: Production of small dimension wood of the main tree species. Lesnícky časopis, 30:309-317.

Požgaj, A., Chovanec, D., Kurjatko, S., Babiak, M., 1993: Štruktúra a vlastnosti dreva. Bratislava, Príroda, 486p.

Raši, R., Cienciala, E., Priwitzer, T., Palán, S., Pavlenda, P., 2015: Carbon balance in harvested wood products in Slovakia. Lesnícky časopis - Forestry Journal, 61:101-106.

Sheikh, A. Q., Skinder, B. M., Pandit, A. K., Ganai, B. A., 2014: Terrestrial Carbon Sequestration as a Climate Change Mitigation Activity. Journal of Pollution Effects \& Control, 2:110. 
Somogyi, Z., 2016: Projected effects of climate change on the carbon stocks of European beech (Fagus sylvatica L.) forests in Zala County, Hungary. Lesnícky časopis - Forestry Journal, 62:3-14.

Steele, S. J., Gower, S. T., Vogel, J. G., Norman, J. M., 1997: Root mass, net primary production and turover in aspen, jack pine and black spruce forests in Saskatchewan and Manitoba, Canada. Tree Physiology, 17:577-587.

Šebík, L. Polák, L., 1990: Náuka o produkcii dreva. Bratislava, Príroda, 322 p.

Šmelko, Š., 2000: Dendrometria. Vysokoškolská učebnica. Zvolen, Technická univerzita vo Zvolene, $399 \mathrm{p}$.

Štěrba, P., Jankovská, Z. (eds.), 2007: National Forest Inventory in the Czech Republic 2001-2004. Brandýs nad Labem, Ústav pro hospodářskou upravu lesů, $224 \mathrm{p}$.

Thorn, A. M., Thompson, J. R., Plisinski, J. S., 2016: Patterns and Predictors of Recent Forest Conversion in New England. Land, 5:30.

Tümen, I., Hafizoglu, H., 2002: Anatomical, physical and chemical properties of wild pear (Pyrus communis L.). In: Naydenova, T., Raev, I., Alexandrov, A., Rossnev, B., Marinov, I., Vassilev, V. D. et al., 2002: Study, conservation and utilisation of forest resources. Proceed- ings of the Third Balkan Scientific Conference, Sofia, Bulgaria, 2-6 October 2001. Volume IV, p. 148-155. van Noordwijk, M., Villamor, G. B., 2014: Tree cover transitions in tropical landscapes: hypotheses and cross-continental synthesis. GLP news, 10:33-37.

Vejpustková, M., Čihák, T., Zahradník, D., Šrámek, V., 2013: Methods of aboveground biomass assessment for European beech (Fagus sylvatica L.). In: Lesnický průvodce 1/2013, Jíloviště-Strnady, Výzkumnýústav lesního hospodářství a myslivosti, 30 p.

West, P., 2010: Tree and Forest Measurement. Dordrecht, Springer, $192 \mathrm{p}$.

Wirth, C., Schumacher, J., Schulze, E. D., 2004: Generic biomass functions for Norway spruce in Central Europe - a-meta-analysis approach toward prediction and uncertainty estimation. Tree Physiology, 24:121-139.

Wutzler, T., Wirth, C., Schumacher, J., 2008: Generic biomass functions for Common beech (Fagus sylvatica) in Central Europe: predictions and compartments of uncertainty. Canadian Journal of Forest Research, 38:1661-1675.

Wutzler, T., Profft, I., Mund, M., 2011: Quantifying tree biomass carbon stocks, their changes and uncertainties using routine stand taxation inventory data. Silva Fennica, 45:359-377. 